\title{
A „szentség aurája” és az ember méltósága Észrevételek Hans Joas szakralizációs téziséról1
}

\author{
Szücs László Gergely \\ https://doi.org/10.51624/SzocSzemle.2019.2.2 \\ Beérkezés: 2019. 01. 14. \\ Átdolgozott változat beérkezése: 2019. 05. 27. \\ Elfogadás: 2019. 06. 21.
}

\begin{abstract}
Összefoglaló: Hans Joasnak a Die Sakralität der Person című műve szerint az emberi jogi normák kialakulásának történeti okai nem elsősorban a vallásellenes szekularizmusra, hanem egy sajátos szakralizálódási folyamatra vezethetők vissza, amelynek során a modern társadalmak a tagjaik körül a „szentség auráját” teremtik meg. Ezt a tézist sokan pusztán történeti-szociológiai elméletként interpretálták. Én viszont amellett érvelek, hogy Joas művének kiemelt célja az emberi jogok legitimációjára vonatkozó új módszertan megalapozása volt. Feltevésem, hogy két szerző (Cesare Beccaria és Michel Foucault) kritikája adott Joasnak alkalmat egy olyan nézőpont körvonalazására, amely szerint a modern egyén adekvát történetének elmesélése és a vele szemben megfogalmazható normatív elvárások feltérképezése komplementer módon kiegészítik egymást. Azt is bemutatom, hogy elsősorban Joas Durkheim-elemzéseinek tanulmányozásával jelölhetjük ki egy új típusú normatív elmélet viszonyítási pontjait. Tanulmányom végén az így rekonstruált elméletet szembesítem az érvényességet a nyilvános helyesléshez kapcsoló észjogi koncepció elvárásaival, így igyekszem felmérni e normatív koncepció erősségeit és korlátait.
\end{abstract}

Kulcsszavak: szakralizáció, emberi jogok, emberi méltóság, történelmi szociológia, normativitás

Hans Joas német szociológusnak A személy szakralitásáról szóló könyve [Die Sakralität der Person. Eine neue Genealogie der Menschenrechte, 2011] szerint az emberi jogi normák kialakulásának történeti okait nem elsősorban a vallásellenes szekularizmusra vezethetjük vissza. Inkább egy sajátos „szakralizálódási” folyamatról van szó, melynek során a modern társadalmak a tagjaik körül a „szentség auráját" teremtik meg. A központi tézis történeti konzekvenciáinak levonása egy nagyobb vallástörténeti mű megírására, Max Webernek a racionalizálódásról, mint a „varázs alóli feloldásáról” szóló elméletének a felülvizsgálatára sarkallta Joast (Joas 2017a: 19-20; Joas 2017b: 7-16), de a szakralizálódáskönyv is a kortárs történeti szociológia fontos munkájává vált. Feltételezésem szerint azonban e munka kiemelt célja az emberi jogok legitimációjára vonatkozó új módszertan megalapozása volt. Érdekes viszont, hogy Joas módszerei a könyv megírása óta eltelt időszakban csak kevéssé vertek gyökeret az emberi jogi diskurzusokban. Ennek egyik oka talán a könyv sajátos interdiszciplináris szemlélete: konklúzióinak megértéséhez az

1 A cikk megírását az MTA Prémium Posztdoktori Kutatói Program támogatta. 
olvasónak egyszerre kell ismernie a filozófiai, szociológiai, történeti, jogi és vallástudományi diskurzusokat. További ok lehet, hogy (ahogyan azt Christoph Möllers jogfilozófus megjegyzi) Joas elmélete igen bátor módon hidalja át az emberi jogokról szóló történeti és politikai diskurzusok résztvevői közötti hagyományos frontvonalakat (Möllers 2011). Így viszont a gondolatmenet egyidejúleg válhatott gyanússá vagy idegenné a front ellentétes oldalain lévő vitapartnereknek.

Joas egyrészt emellett érvel: ahhoz, hogy az emberi jogok mibenlétét megvilágíthassuk, elsősorban a jogok kialakulásának vallási feltételeire kell tekintettel lennünk. Az emberi jogi normák megértéséhez tehát nem elég a szekuláris intézményrendszer felől közelíteni. Másrészt viszont élesen támadja azt a megközelítést, amely az emberi jogok és a keresztény értékrend között problémamentes megfelelést lát. ${ }^{2}$ A kereszténység valójában igen hosszú „tanulási folyamat” során alkalmazkodott az emberi jogi normarendszer sajátos modern „innovációjához” (Höffe 2011). További érdekes feszültség, hogy Joas nem tagadja meg az emberi jogok univerzális érvényességi igényét. De - Rawlstól és Habermastól eltérően - úgy látja: az emberi jogi normák érvényességét nem lehet pusztán a történeti kontextustól elvonatkoztatott univerzális morális diskurzusban megalapozni. Joas szerint az emberi jogok univerzális érvényességi igénye csak egy sajátos történelmi-társadalmi szituációban válik világossá, így az érvényesség igazolásának elengedhetetlen feltétele a történetszociológiai gyökerek megragadása is (Möllers 2011).

Otfried Höffe kantiánus filozófus igen szkeptikus Joas projektjével szemben. Joas egy „affirmatív genealógia” megalkotására törekszik: egy olyan módszer kidolgozására, amelyet követve egyszerre tekinthetnénk át az emberi jogok kialakulásának „hiteles történetét”, és jutnánk el a jogok érvényességigényének elismeréséhez. Csakhogy a mai teoretikusnak a klasszikus történelemfilozófiai perspektívával szemben megfogalmazott szkepszise annak elfogadását jelenti, hogy lehetetlen áthidalni a történeti esetlegességeket számba vevő genezis és az észszerú igazolás kritériumrendszerét számon kérő filozófia közti szakadékot. Így nagyon nehéz belátni, hogy a történeti genezis módszerének követésével hogyan juthatunk el a jogi normák érvényességének igazolásához. Höffe szerint így a legjobb esetben is csak „elfogadhatóságuk”, „plauzibilitásuk” bemutatására nyílik lehetőségünk. Természetesen elismerhetjük egy interdiszciplináris projekt létjogosultságát, amely a hagyományos kantiánus filozófussal szemben azt mutatja be, hogy az emberi jogi normák további terjedéséhez a filozófiai argumentáción túl az intézményi háttérfeltételek biztosítására és e normáknak a mindennapi gyakorlatban való meggyökeresedésére is szükség van. Joas elemzése azonban, amely leginkább Durkheimre támaszkodik, nem egészül ki racionális érvényességi igényt számon kérő filozófiai érveléssel (Höffe 2011). Höffe ezért Joas művét a szociológus illetéktelen behatolásaként értelmezi a

2 A 2000-res évek Németországában Tine Stein képviseli legmarkánsabban azt az álláspontot, hogy a zsidó és keresztény gondolkodás, a zsidó/keresztény alapokon nyugvó intézményi háttér nélkül nem jöhetett volna létre demokratikus jogállam; Stein szerint az emberi méltóságra vonatkozó normatív igényünk csak e vallási-teológiai háttér kontextusában értelmezhető (Stein 2007: 13). 
racionális filozófiai argumentáció területére, amellyel szemben a klasszikus filozófia apologetikájának kidolgozására lenne szükség (Fonk 2013: 127-128).

Feltevésem szerint azonban Joas tudatában volt e lehetséges ellenvetéseknek, és írásait e dilemmák feloldására szolgáló kísérletekként is olvashatjuk. Szakralitáskönyve rengeteg szociológiai és elméleti problémát tárgyal, és módszertanát tekintve is rendkívül plurális. A könyv gondolatmenete az észak-amerikai és francia deklarációk hatástörténetének elemzését (1. fejezet), az emberi erőszak rövid történetének, az erőszak-tapasztalat történeti változatainak bemutatását is felöleli (3. fejezet). Az elméleti fejezetek Ernst Troeltsch német idealizmuskritikájának elemzésével, a genealogikus módszer újraértelmezésével (4. fejezet) és az értékgeneralizálás problémájával (6. fejezet) is foglalkoznak. Dolgozatomban - nem tévesztve szem elől a többi fejezet tanulságait - leginkább a második fejezetre fókuszálok. E fejezet érdekessége, hogy látszólag tisztán történelemszociológiai szöveg, amelyben Joas a jogfejlődés tendenciáit adekvát módon kifejező történeti modell megtalálására törekszik. Feltételezésem szerint viszont Joas e szövegben történeti példák bemutatásán túl saját módszertani előfeltevéseinek tisztázására törekszik. E fejezetben ötvözi legérdekesebben a filozófiai és a szociológiai nézőpontot: egyszerre próbálja elmondani a normák történetét és megvizsgálni érvényességük alapjait. Elméletét e fejezeten keresztül a már felmerült kérdés felől vizsgálom: a látszólag tisztán történelemszociológiai elemzésből kibontható-e a normatív megalapozás mikéntjére vonatkozó filozófiai elmélet? Kérdés az is, hogy egy a normák és értékek esetlegességével számot vető történeti koncepcióval bármilyen módon összeegyeztethető-e egy univerzális érvényességi igényekkel fellépő normatív társadalomelmélet projektje.

Dolgozatom első részében Joas Cesare Beccariáról és Michel Foucault-ról szóló kritikáját vizsgálom. Joasnak e két szerzőről szóló interpretációja látszólag egy történeti kérdést érint: hogyan mondhatjuk el a nyugati büntetési kultúrának az egyénnel szemben megnyilvánuló erőszaktörténetét. Feltevésem szerint azonban e két szerző kritikája Joasnak alkalmat ad egy olyan nézőpont körvonalazására, amely szerint a modern egyén adekvát történetének elmesélése és a vele szemben megfogalmazható normatív elvárások feltérképezése komplementer módon kiegészítik egymást. Ezután Joasnak a Durkheimről szóló elemzéseire irányítom a figyelmemet. Bemutatom, hogy a „személy szakralizálódásáról” szóló durkheimi koncepció rekonstruálásakor nem pusztán a Beccaria és Foucault problémáit kiküszöbölő modernizációelmélet felvázolása Joas célja: a Durkheim-elemzések egy normatív elmélet alapvető viszonyítási pontjait is rögzítik. Tanulmányom végén az így rekonstruált elméletet szembesítem az érvényességet az észszerű, nyilvános helyesléshez kapcsoló észjogi koncepció elvárásaival, így igyekszem felmérni e normatív koncepció erősségeit és korlátait. 


\section{A kínzás tilalma és a felvilágosodás perspektívája}

Joas szerint az emberi jogok mibenlétének feltárásához nem elegendő a késő 18. századi emberi jogi deklarációkat teoretikus elemzés tárgyává tenni. Inkább a keletkezés körülményeire érdemes fókuszálni: azokra a kulturális változásokra, amelyek azt eredményezték, hogy a modern individuum univerzális jogokkal bíró személyként gondolhat önmagára. Az érvényesség forrásainak megtalálásához azt a társadalmi helyzetet kívánja bemutatni, amelyben a deklarációk termékeny talajba hullhattak: a nyilatkozatok megfogalmazásakor már embertömegek fedezhették fel bennük önértelmezésük, autonómiaigényük kifejeződését. Szerinte az európai büntetési kultúra változásai jelölik ki azt a jelenségcsoportot, amelyen keresztül a „mélyen zajló kulturális transzformáció” sajátosságai feltárhatók. A kulturális változás kezdőpontja a 18. század első fele: ekkortól kezdve a kínvallatást egyre kevésbé tekintették az igazság kiderítésére és a vallomás kikényszerítésére szolgáló legitim módszernek Európában. Ezzel párhuzamosan a nyilvánosság előtt, látványosságként bemutatott kínszenvedés egyre kevésbé volt elfogadott módja a büntetés végrehajtásának. Már a deklarációk előtt megkezdődtek az arról szóló viták is, hogy az állam legitim módon rendelkezik-e polgárai élete felett. A folyamat fontos állomása volt a modern nyugati börtönnek mint a büntetés-végrehajtás tipikus intézményének a megszületése. Jóval későbbi eredménye pedig a halálbüntetés tilalma a legtöbb európai és észak-amerikai államban (Joas 2011: 64).

A Joas által vizsgált elméletek átfogó történeti keretben értelmezik a büntetőjog változásait. De Joas azt is be akarja mutatni, hogy ezek az elméletek normatív értékítéleteket is meghatároznak társadalmunkra nézve. A kínvallatás módszerének háttérbe szorulását rendszerint a felvilágosodás narratívájában mondjuk el. Joas ezért először Cesare Beccaria 1764-es A bűnözésről és a büntetésről szóló múvét elemzi: ez a felvilágosodás szellemiségében íródott legátfogóbb mű, amely a legitim büntetés forrásairól szól. A mű hatástörténete is fontos: híres francia fordítása révén Voltaire, Diderot és d'Alembert gondolkodására is döntő hatással volt, és francia közvetítéssel az európai büntetőjog meghatározó művévé vált (Joas 2011: 66). A könyvben megjelenő társadalomkép szerint a politikai társadalmakat évszázadok óta értelmetlen szokások uralják: a „büntetőeljárás” által megengedett kínzás és erőszak egy meghaladott kor maradványa, amelyet lustaságból nem győztünk le. Ez a történeti koncepció a felvilágosult értelmiségi pozícióját is kijelöli. A filozófus feladata egy olyan módszer felkutatása, amellyel a haszontalan szokások és a meggyökeresedett előítéletek világa mögött felfedezhetővé válik a hatalmi viszonyoknak nem alávetett, őseredeti, racionális egyén. A filozófus azonban Beccaria szerint nem rendelkezik azokkal az eszközökkel, amelyekkel az eredeti racionális elvárásoknak megfelelő társadalom berendezhető. Elmélkedéseinek címzettje így a felvilágosult és jóakaratú monarcha, aki a szokások rabjává vált elit és a barbárságba hullott tömegek ellenállását letörve gondoskodik a társadalom észszerű berendezéséről (Joas 2011: 67). 
Beccaria a „történelem előtti” egyéneket szabad, szerződéses viszonyra törekvő felekként jellemzi. A szerződéskötést meghatározó elvet a politikai gondolkodás későbbi történetéből az utilitarizmus alapelveként ismerjük: akkor járunk el helyesen, ha „minél nagyobb boldogságot” juttatunk „minél több embernek” (Beccaria 1967: 53). A büntetőeljárás lehetőségét a társadalmi szerződés teremti meg: a büntetés kizárólagos célja annak megakadályozása, hogy a társadalom tagjai abba a kaotikus állapotba hulljanak vissza, amelyben életüket és tulajdonukat veszélyben látják másokkal szemben. Így a legitim büntetés határát is a szerződés határozza meg. Azok a büntetések, amelyek veszélyeztetik a szerződés vívmányait vagy az egyén természetes szabadságát, jogtalanok. Beccaria úgy látja, hogy a büntetőtörvények így egy deduktív rendszerben a szerződés elveiből kikövetkeztethetők. Szerinte az is számszerűsíthető, hogy egyes cselekedetek milyen mértékben segítik elő vagy gátolják a közjó érvényesülését. Ha ez igaz, a legitim büntetés mértékét egy kvantitatív viszonyrendszerben határozhatjuk meg. Eszerint a társadalomnak akkora (és éppen csak akkora) erővel kell a társadalom egyes tagjaival szemben fellépnie, amekkora veszélyt jelent a cselekvésük a közjóra, és amennyire eltökélt a próbálkozásuk arra nézve, hogy a büncselekményüket végrehajtsák (Joas 2011: 68).

A kínzáson alapuló büntetés és a kínvallatás irracionalitása ebben a formális rendszerben válik szembetűnővé. Beccaria a „csökkenő határhaszon törvényének” egy korai, sajátos változatát fogalmazza meg. Eszerint az a társadalom, amely bestiális büntetésekkel fenyegeti tagjait, valójában fokozatosan hozzászoktatja őket az ellenük irányuló agresszió elviseléséhez. Mivel minden egyes büntetés után lépésenként válnak egyre immunisabbá a fájdalomra, a politikai társadalomnak egyre jobban „növelnie kell a tétet”, és egyre kegyetlenebb módszereket kell alkalmaznia a bűnözés megfékezésére. Beccaria ezzel szemben úgy látja, hogy a mértékletes büntetések következetes és kiszámítható végrehajtása sokkal eredményesebb a közjó védelmezése szempontjából, mint a szélsőségesen erőszakos megtorlás kilátásba helyezése. A kínvallatás inkább tűnik az ellenállási készség tesztjének, mint az igazság kiderítésére szolgáló eszköznek. Alkalmazása a társadalom szempontjából teljesen diszfunkcionális: a kínvallatásnak inkább eltökélt és erőszakos bűnözők állnak ellen; a gyenge ártatlanok, akik a társadalom hasznosabb tagjai, hamar megtörnek (Joas 2011: 69).

A halálbüntetés jogtalansága is a szerződéses viszony természetéből következik. A szerződő feleknek, akik életüket és tulajdonukat veszélyben látják, jól kalkulálható érdekük, hogy privát szabadságuk legkisebb részét áldozzák fel a nyugalom vagy a közjó érdekében. A szerződésben tehát nem adják föl az életük fölötti rendelkezés jogát. Eszerint az állam, amely halálbüntetést alkalmaz, csak látszólag cselekszik a legitim büntetőnormák szerint, valójában saját polgárai ellen visel háborút. Elképzelhető persze a ritka eset, hogy valaki szélsőségesen veszélyes a szerződéses rendszer fenntartására; elszántságának és szervezőkészségének a börtön sem képezi akadályát. Ha ekkor a politikai hatalom kénytelen a halálbüntetés eszközével élni, 
az észszerúség azt kívánja, hogy a büntetés végrehajtása törvényileg szabályozott módon, nyilvánosan, gyorsan és a legkevésbé fájdalmasan történjen. Beccaria kritikája itt válik igazán élessé, hiszen a kivégzés gyakorlata még fejlettebb társadalmakban sem felel meg a felvázolt észszerű elveknek (Joas 2011: 69-70).

\section{A „felvilágosodás mítoszának” kritikája}

Joas szerint Beccaria sok filozófushoz hasonlóan túlértékeli azt a szerepet, amelyet a társadalmi szerződés gondolata a humánus eljárások megteremtésében játszik. Beccaria maga is elismeri, hogy több korabeli királyságban már az elméletének megalkotása előtt komoly erőfeszítéseket tettek a kínzás visszaszorítására: Svédországban 1734-ben, II. Frigyes Poroszországában a negyvenes években hivatalosan betiltották a kínvallatást (bár a tényleges gyakorlat ennek sokszor ellentmondott). Franciaországban a 18. század közepe óta szabtak korlátokat a kínzáson alapuló eljárásnak. Téves tehát a kép, amely egyszeri aktusként ábrázolja a hatalmi visszaélés visszaszorítását. Nem egy semmiből jövő „megállapodásról”, hanem egy a felvilágosodás előtt elindult, komplex társadalmi folyamatról van szó (Joas 2011: 70). Itt érdemes megjegyezni, hogy Joas ezen a ponton a történeti szociológia igen nehezen járható útjára téved. Azt feltételezi, hogy a kínzásnak, a kínvallatásnak Európa eltérő színterein többé-kevésbé egyidejű háttérbe szorítása mögött nem pusztán az uralkodó individuális döntéseiről van szó, hanem széles körben teret hódító kulturális változásról. Ugyanakkor tudatában van annak, hogy több száz év távlatából nehezen mondhat bármit is a „társadalmi érzület megváltozásáról”, annak irányáról, vagy arról, hogy a társadalom mely rétegeit érinti a változás, ezért rendkívül óvatosan jár el: leginkább az általa fontosnak ítélt szerzők (mindenekelőtt Beccaria, Durkheim és Foucault) által felhozott empirikus példákból indul ki, rendszerint e példákat ellenőrzi széles körű történeti tudásának bázisán. Majd e példákat újabb és újabb történeti narratívában próbára téve reméli, hogy átfogó hipotéziseket tud megfogalmazni a „társadalmi érzület” megváltozásáról.

Joas Beccaria-kritikájára visszatérve viszont elmondhatjuk: az a kritika, amely szerint nem a társadalmi szerződés elméletén nyugvó racionális belátás, hanem egy mélyen zajló társadalmi folyamat vezetett a kínzás illegitimmé válásához, nem hatol túl mélyre. Kézenfekvő az ellenérv, hogy a szerződéselméleti szerzők az észszerű megállapodás feltételeinek rögzítésekor nem a normaérvényesség történeti feltételeiről írnak. Joas mintha figyelmen kívül hagyná, hogy minden szerződéselmélet lényegét tekintve hipotetikus: azt térképezi fel, mely normákat tekinthetünk legitimnek, ha a történeti valósággal szembehelyezzük azt a képet, amely szerint a társadalom racionális felek megállapodásának eredménye. Az az érvelés tehát, amely a fiktív és feltételes megállapodás szituációjával szemben a szerződéskötés folyamatának „történeti hiteltelenségére” hivatkozik, teljesen irreleváns a normaérvényesség racionális igazolásának szempontjából. 
Azonban másképp is érvelhetünk: tegyük fel, hogy a század derekára kialakult egy olyan helyzet, amelyben a kínzás a múvelt közvélemény ellenérzéseibe ütközött (bár ahogy említettem, a „társadalmi érzület” megváltozásáról szóló hipotézisek ellenőrzéséhez nincsenek megbízható eszközeink). Ha Joasnak ez a feltételezése helytálló, akkor megalkotható egy módszer, amely ennek az „intuitív” kínzásellenességnek racionális megalapozást nyújt. Ebből a szempontból - Joasszal ellentétben - a szerződést semmiképp sem tekinthetjük a társadalmilag meggyökeresedett normák forrásának. Inkább egy olyan eljárás mintájának, amely egy logikai rendszerben lehetővé teszi az intuícióinkkal, megfontolt ítéleteinkkel összecsengő általános elvek generalizálását. ${ }^{3}$ Vagy egy olyan eljárásnak, amely az újonnan megalapozandó polgári társadalom intézményrendszerének alapjait határozza meg, amely azonban nem törekszik a társadalmi érzület átalakítására.

Joas kritikája azonban elmélyíthető. Feltételezésem szerint azt mutatja be, hogy a szerződéselmélet rejtett történeti előfeltevéseket hordoz, és így ezzel az elmélettel szemben a „valós történet” bemutatása az elmélet normatív következményeire is hatással van. Beccaria felvázol egy narratívát a társadalmi érzület átalakulásáról. Szerinte saját kortársai más korok emberével szemben sokkal „érzékenyebbé” váltak a szenvedésekkel szemben. Ennek szerinte két történeti oka van: egyrészt a növekvő jólét miatt az emberek kifinomultabbá váltak, és az emberi tévedéssel szembeni türelmük megnövekedett. Másrészt a könyvnyomtatás elterjedése a törvények széles körü ismeretének kedvezett (Joas 2011: 71).

Beccaria ezt a leegyszerúsített történetet, amelyben a civilizált jelent egy egyszeri megvilágosodás, egy gyors tanulási folyamat vagy valamilyen „gyarapodás” választja el a barbár múlttól, egy öröknek tételezett norma nézőpontjából „mondja el”. Mint a legtöbb szerződéselméleti szerző, azt feltételezi, hogy az emberi élet védelme az emberi szívbe legmélyebben beleírt erkölcsi parancs. Ez azt jelenti, hogy a büntetőjog, vagy akár az egész emberiség története is, e törvény világos felismerésén fordul meg. A történész persze felismeri, hogy a korábbi jogrendszerek hallgatólagosan sem előfeltételezik az emberi élet védelmének elsődlegességét: a blaszfémia és az istenkáromlás megbüntetése valójában mindig előbbre való volt az egyszerű, profán élet kioltásának szankcionálásánál (Joas 2011: 72). Fontosabb azonban, hogy e normák felől a jogtörténet is adekvátabb módon mondható el: a felvilágosodás perspektívájából a múlt egyneműnek és zavarosnak tűnő világa logikusabb rendben jelenik meg. Olyan társadalmak képe tárul fel, amelyek a szentség meggyalázását és a felségsértést a lehető leghatékonyabban próbálják szankcionálni - az adott társadalom képességeinek és a világ rendjéről alkotott képének megfelelően.

Joas kritikájának lényegi része annak bemutatása, hogy Beccaria a szerződéselmélet kontextusában nem tud hitelesen számot adni a modern egyén büntetéssel

3 El kell ismerni, hogy ez az értelmezés a huszadik századi, rawlsi koncepció visszavetítése lenne egy klasszikus szerződéselméletre. Mivel azonban Joas Beccarián keresztül a modern szerződéses hagyományt kritizálja, az ellenérvet használhatónak érzem. E Rawls-értelmezéshez Id.: O’Neill (2006: 39). 
kapcsolatos morális intuícióiról. Egyrészt nem tud mit kezdeni azzal, hogy a felvilágosult világ is megvetéssel illeti, sok esetben szankcionálja is az öngyilkossági szándékot. Ez a társadalmi szerződés formális rendszerében észszerütlen. Ha a természeti állapot felei az életük fölötti rendelkezés jogát nem adják át a társadalomnak, akkor érthetetlen, miért nem rendelkeznek azzal a szabadsággal is, hogy saját életüket kioltsák. Ahogy az is érthetetlen, miért nem illeti az öngyilkosnál nagyobb megvetés és büntetés azt, aki kivándorol országából. Míg ugyanis az öngyilkos hátrahagyja a vagyonát a társadalom tagjai számára, a kivándorló a javaival együtt hagyja el a szerződéses közösséget, megkárosítva a társadalom összjövedelmét, és akadályozva a közjó elérését. Problémát jelent az is, hogy Beccaria alapvetően az utilitarista elvre hivatkozva érvel a társadalmi szerződés szükségessége mellett. Így végül elmélete nem képes számot adni annak a meggyőződésnek a normatív forrásáról, amely szerint minden ember élete védelemre szorul. A szerződéses koncepció logikai rendszerében a végső normatív ítélet a közösségnek vagy a szerződő felek többségének hozott haszon függvénye. E pozícióból azonban nehéz megvilágítani, hogy a közjó szempontjából értékes és értéktelen emberi élet kioltását miért tartjuk egyaránt szörnyű bűntettnek, és hogy a büntetőjog miért nem megengedő a „haszontalan élet” kioltásával szemben. A kritikákat talán így általánosíthatjuk: a modern szerződéses hagyomány nézőpontjából egyrészt nehéz megmagyarázni, hogy a modern társadalmakban, ahol az egyéni autonómia a legfőbb érték rangjára emelkedett, az egyén messze nem rendelkezik olyan szabadon saját élete, mint saját tulajdona felett. Másrészt e nézőpontból érthetetlen, hogy ugyanezekben a társadalmakban az egyéni élet védelmének univerzális igényű parancsa hogyan függetlenedett a döntően meritokratikusan, a vélt társadalmi hasznosság által dominált értékhierarchiától. ${ }^{4}$

Úgy tûnik, Joas célja egy olyan tágabb történeti perspektíva bevezetése, amelyből a szerződéselméleti felfogás alapfeltevései tévesként vagy legalábbis történetileg kontingensként mutathatók fel, és amelyből kiindulva adekvátabb képet kaphatunk magunkról mint modern értelemben vett morális cselekvőkről. Fontos azonban felhívni a figyelmet, hogy Beccaria jogelméletéről alkotott kritikája nem érintette a szerződéselméletek normatív tartalmának minden elemét. Fontos például, hogy a társadalmi szerződés gondolata annak a modern elvárásnak a kifejeződése, hogy egy törvény vagy egy norma legitimitásának általános elvek észszerủ helyeslésén kell nyugodnia. Joas itt formálódó koncepciója azt üzeni, hogy a modern ember autentikus és szabad életének fontos előfeltétele, hogy a múltjáról megfelelő értelmezést adjon, és felismerje saját történeti helyzetét. Kérdés, hogy ez a társadalomkép hogyan egyeztethető össze azzal a szerződésgondolatban jogosan meglévő előfeltevéssel, hogy az életünket uraló normák legitimitása nem csak megszokáson, de valami-

4 Axel Honneth a személyhez kötött értékek párhuzamos „demokratizálódását” és „meritokratizálódását” a polgári kapitalista társadalom és a modernizáció egyik legdöntőbb tendenciájának tartja, Id. például Honneth (2003: 163). 
lyen szabad és racionális választáson, nyilvánosan is számon kérhető egyetértésen kell hogy nyugodjon.

\section{Totális kontroll és társadalmi inklúzió}

Joas egy olyan elméleti alternatíva felrajzolását tekinti feladatának, amely megragadja a modernség előtti büntetőjogi rendszer logikáját, és amely lehetővé teszi, hogy a büntetőnormák premodern gyökereinek feltárásával a modernség illúzióira is rávilágítson. Így nem meglepő, hogy elméletében Michel Foucault Felügyelet és büntetés címú múvére is hivatkozik. Foucault a köznapi érintkezés szintjén a párbaj logikája felől világítja meg a régi, vérontáson alapuló büntetés sajátosságát. Ahogy a párbaj, úgy általában a premodern „büntetés” sem egy formális szabály megsértését szankcionálja, hanem egy „egyszeri tettet”, valaki erkölcsi integritásának megsértését, egy az életútban okozott törést. Foucault a központi hatalom oldaláról azokat a brutális kínzásokat tanulmányozza, amelyeket az abszolutista rendszerek nyilvános, ünnepi esemény rangjára emeltek. Így a kínzást végül olyan rituáléként jellemzi, amelynek során az uralkodó helyreállítja a bünelkövető által megsértett szuverenitását. A kínszenvedés, a fizikai fájdalom ebben a rendszerben a büntetés kiküszöbölhetetlen részeként jelenik meg: a hatalom „természetes” rendje csak úgy állítható helyre, ha a bűnös a szuverén „hatalmának lángjában megég”. A felvilágosodás jellegzetes értelmezésével ellentétben tehát a kínzáson alapuló büntetés nem interpretálható a barbár törzsi leszámolás maradványaként. Valójában egy sajátos jogrend logikus és nélkülözhetetlen eleméről van szó. E rendszerben minden törvénysértés a szuverén (a törvény forrása) elleni közvetlen támadásként, azaz felségsértésként értelmezhető. A kisebb bűntettek abszolút viszonyítási pontja a legfőbb bűn: az uralkodó elleni nyílt lázadás. Így a büntetéssel járó kisebb fizikai fájdalom is végső soron a kínhalál fájdalmára, azaz a szuverén hatalmának rituális újrateremtésére kell hogy emlékeztessen (Foucault 1990: 66-67; Joas 2011: 78). Foucault azonban (ebben a múvében) nem fordít figyelmet azokra az összefüggésekre, amelyek a szuverenitás alapjainak megváltozásából adódnak. A modernség történetét inkább a társadalmakat minden körülmények között átstrukturáló absztrakt uralom nézőpontjából mondja el, és a büntetési kultúra átalakulását a hatalomtechnikában bekövetkező változásokra vezeti vissza. Ezért áll művében kitüntetett helyen a modern börtönök történetének leírása a kazamaták világától a „szellem uralmára” törekvő modern börtönön át a totális megfigyelést lehetővé tevő panoptikonig.

Joas Foucault-kritikájának alapját Marcel Gauchet-nek egy másik fontos Foucaltműről, Az őrültség történetéről szóló észrevétele alkotja. Foucault szerint az őrültet a középkorban a „teremtés normális részének” tekintették: ez a világkép nagyfokú társadalmi elfogadáshoz vezetett a társadalom többi tagja részéről. A felvilágosodással, az „ész kultúrájának” a megteremtésével azonban ez a szemlélet gyökeresen megváltozott, és a hatalom a totális intézmények létrehozásával (elmegyógyintézet, 
őrültekháza) gondoskodott az őrültek „távoltartásáról”, társadalomból való kirekesztéséről. Gauchet szerint azonban Foucault elmélete tévedésen alapul: a középkori „toleranciában” valójában a legradikálisabb távolságtartás nyilvánul meg: az őrült nem az emberi nem része, teljesen eltérő helyet foglal el a teremtés rendjében, ebből fakadóan kevés figyelmet kíván. E szemlélet döntően az abszolutista társadalomszervezés hatására változik meg (ezt Gauchet már a modernség fontos részének tekinti), amely úgy akarja meghaladni a középkor gazdagon differenciált társadalmát, hogy mindenkit az abszolút hatalom alattvalójává, ezáltal a társadalom részévé tesz.

Joas szerint az őrült és a bűnöző helyzetében analógiát figyelhetünk meg. Felismerhető ugyanis, hogy a nyugati társadalmakban csak egy modernizációs folyamatot követően jelenik meg az az igény is, hogy a bűnözőt mint a társadalom egyenértékű tagját „visszaillesszék a társadalomba”. Ebből azt a következtetést vonja le, hogy a börtönnek - és általában az új intézményeknek - azt a törekvését, hogy a viselkedést kontrollálják, megelőzi egy eredendőbb folyamat: az abszolutista hatalomgyakorlástól a homogén nemzetállamokon, az állampolgári nemzetállamokon át a szociális államig azonosítható kihívás, hogy egy egységes társadalom jöjjön létre; hogy a társadalom egyes, korábban integrálhatatlannak tekintett tagjait növekvő mértékben vonják be a társadalmi folyamatokba (Joas 2011: 79). A felvilágosult vagy utilitarista társadalomreformereket ebből a szempontból nem tekinthetjük pusztán az elvont uralmi gépezet öntudatlan kiszolgálóinak. E pozícióból azok a tervek, amelyek a növekvő megfigyelés, szellemi kontroll vagy a cselekvés kalkulációja irányába hatnak, nem a modernség kiküszöbölhetetlen elemei. Inkább a megoldhatatlannak tűnő kihívására adott inadekvát, olykor torz és emberellenes válaszokként értelmezhetők: arra a kérdésre adott feleletként, hogy hogyan hidalható át a társadalmi gyakorlat során az ember és ember közötti, a társadalmi-kulturális háttér különbségéből, a szocializációból, mentális vagy fizikai különbségekből adódó szakadék.

\section{Az integráció vallási gyökerei}

Joas Foucalt-kritikájából kiderült, hogy egy olyan történeti nézőpont megalkotására van szüksége, amelyből kiindulva a hatalom humanizációjának reális perspektívája is felvázolható. Joas így Émile Durkheim társadalomtörténeti elemzéseihez fordul. A „személy szakralizálódásáról” szóló nézetet, amelyet Joas nem csak a vizsgált változás, de a modernizáció mibenlétének megragadásához is döntőnek tekint, Durkheim szisztematikus formában nem fejtette ki. Joas azonban a francia szociológus több múvét együtt olvasva rajzol fel egy lehetséges elméletet, és annak tanulságait igyekszik gyümölcsözővé tenni egy normatív társadalomfilozófia számára.

Durkheim társadalmi integrációról szóló kiforrott elméletének elemei a Társadalmi munkamegosztásról szóló könyv néhány korábbi gondolatával kontrasztba állítva világíthatók meg. Durkheim 1893-as múvében még hajlik arra, hogy a modern individualizmust alapvetően a társadalomra leselkedő veszélyként írja le, a modern 
individuumhoz a személytelenség eszméjét társítsa (Durkheim 2001: 300-301). Úgy gondolja, hogy az „individuum kultusza” ugyan lehetővé tette a modern társadalmak sajátos működését, hiszen az egoisztikus preferenciák szem előtt tartása kikényszerítette az egyéni cselekvések új típusú koordinációját. Ekkor azonban még úgy gondolja, hogy a hagyományos társadalmakhoz képest nem jött létre morális alapú társadalmi kötelék és nem adott a kényszermentes együttmúködés lehetősége (Joas 2011: 87).

További tanulmányai e nézet felülvizsgálatára ösztönözték Durkheimet. A Joas által idézett $A z$ individualizmus és az értelmiségiek című 1898-as tanulmányában az általunk vizsgált korszakban két egymást kiegészítő társadalmi-strukturális tendenciát azonosít. Egyrészt úgy látja, hogy a modern társadalmi rendszerek kiformálódásának alapja a hatalmas, de együttmúködésre képes társadalmi formációk létrejötte. Ezekben a társadalmakban már lehetetlen egy mindenki számára azonosulásra méltó tradíciót találni, amelynek mentén aztán a társadalmi cselekvés is öszszehangolható lenne. Párhuzamos folyamat a társadalmi munkamegosztás differenciáltabbá válása, amely felerôsíti a hatalmas társadalmak előtt álló modernizációs kihívást. A hatékony termelés érdekében eltérő kulturális hátterű egyéneknek kell azonos térben és időben egymással hatékonyan együttmúködniük. Ráadásul úgy, hogy ezek a cselekvők - éppen a foglalkozás és a tudás erősödő specializációjának eredményeképpen - egymástól egyre távolodó perspektívából tekintenek a világra (Durkheim 1986: 63; Joas 2011: 89).

Könnyen belátható, hogy valaki csak észszerű meggyőzés vagy (még inkább) őszinte vallásos érzés megélésével válhat egy vallás hívévé. Durkheim ezért meglehetősen kritikus azokkal a kortársaival szemben, akik úgy gondolják, hogy a modernizációban tapasztalható atomizálódásra a tradicionális hit helyreállítása lehet a válasz. A társadalmi integráció kihívása, a morális kötelékek helyreállítására való hivatkozás nem nyújt racionális alapot a vallásos hittételek elfogadásához és a vallási érzület kikényszerítésének sem hatékony módja: állami kényszer nem tudja helyreállítani az egyszer már elvesztett tradicionális-vallási kötelékeket. Ugyanakkor úgy vélte: a társadalom integrációja nem valósítható meg pusztán azáltal, hogy egy központi hatalom közös morális nézőpont nélkül egyszerűen kikényszeríti az „egynemü” cselekvések végrehajtását. Kérdés tehát, hogyan ragadható meg a normatív viszonyrendszer, amely elősegítette a komplex társadalmak tagjainak kényszermentes együttműködését?

Durkheim történetileg a kereszténységben véli felfedezni „a modern hitrendszer” gyökereit. A kereszténység az antik városállamok vallásaival szemben a morális élet centrumát a külső ceremóniákból az egyén belső világába helyezte át. A vallásosságot így az individuális szinten megszülető meggyőződéssel kapcsolta öszsze: az egyén saját magán és Istenen kívül senkinek nem tartozik elszámolással. Ez a tradíció így korlátozott formában magában foglalja az individuális autonómiaeszmény alapjait: az egyént egyszerre tekinti saját cselekvése forrásának és - az isteni 
törvény alapján - szuverén bírájának. Durkheim azt feltételezi, hogy a modernizáció hajnalán ebből az eszményből egy új típusú normatív rendszer nőhetett ki, amelyben már nem a közös Istenben való hit és a köré épülő rítusok, hanem közvetlenül a másik személlyel mint önálló döntésre képes egyénnel való azonosulás teremti meg az együttmúködés alapját (Durkheim 1986: 64).

\section{A szentség durkheimi fogalma}

Kérdés, hogy ez az új normatív rend mennyiben függetlenedett eredeti, vallási gyökereitől. Ahhoz, hogy erre a kérdésre választ adjunk, érdemes röviden áttekintenünk a durkheimi vallásszociológia Joas szempontjából fontos alapgondolatait. Durkheim A vallási élet elemi formái címú 1912-es múvét egy arra irányuló kísérleteként lehet megragadni, hogy a történelemben tapasztalható szerteágazó „vallási fenoméneket” egy egységes vallásdefinícióban egyesítse, és ezáltal lehetővé tegye az összehasonlító elemzésüket. Durkheim egyrészt szembefordul azzal a megközelítéssel, amely szerint a vallás misztikus élményhez köthető. A lehetséges definíciókból kimaradnának a „primitív” totemista vallások, amelynek hívei nem osztják fel a világot „természetesre” és „misztikusra”. De ha utólag feltesszük a világ ilyen felosztását, azt kell mondanunk, hogy vallásos gyakorlatuk éppen a természethez és nem a természetfeletti szférához kötődik. Azt a felfogást, amely a vallást az isten fogalmán keresztül definiálja vagy valamilyen szellem-lény elfogadásához kapcsolja, Durkheim a buddhizmus példáján keresztül cáfolja: ebben az esetben egy isten nélküli vallásról beszélhetünk, amely pusztán a kinyilatkoztatott tan követésére épül (Durkheim 2003: 39).

Durkheim ezért inkább két ellentétpárra építi vallásdefinícióját: a szent és a profán, valamint az egyéni és a közösségi ellentétére. Egyrészt úgy gondolja, hogy a különböző vallások követői a képzeteiket igen határozottan a szakrális és a profán egymással szembenálló osztályaiba sorolják. Durkheim ezt a létező társadalmak két, legradikálisabban szembenálló kategóriájaként mutatja be, és úgy gondolja, hogy átmeneti természetű dolgok, személyek nem lehetségesek. Első meghatározása szerint szent dolgok azok, amelyeket tiltások védenek, profán dolgok pedig azok, amelyekre e tiltások vonatkoznak - abból a célból, hogy távol tartsák őket a szenttől. A másik, az egyéni/közösségi ellentétpár amiatt kap fontos szerepet Durkheim meghatározásában, hogy el lehessen különíteni a magányosan vagy a privát kliensek előtt gyakorolt mágikus tevékenységet a kollektív módon gyakorolt vallástól. Durkheim reményei szerint így válhat világossá, hogy a vallás egy átfogó morális értékrend letéteményese. A felvázolt két ellentétpár mentén így a következő vallásdefiníció rajzolódik ki: „[a] vallás szent, vagyis elkülönített és tiltott dolgokra vonatkozó hiedelmek és gyakorlatok összefüggő rendszere, amely a híveket az egyháznak nevezett morális közösségben egyesíti" (Durkheim 2003: 45-46).

Durkheim tudatában van annak, hogy felvázolt vallásdefiníciója továbbgondolásra szorul. Egy kézenfekvő kritika szerint e vallásmeghatározás legnagyobb prob- 
lémája, hogy egy másik homályos, definícióra szoruló, általános fogalmat, a szent fogalmát helyezi a vallásról szóló fejtegetései középpontjába. Így lényegében eltolja a definíciós problémát. ${ }^{5}$ Lehetne persze úgy érvelni, hogy egy szociológiai elemzés számára nem szükséges a szentségről közelebbi meghatározást adnunk: éppen elég, ha a két fogalom hozzávetőleges orientációs pontot képez az empirikus kutatás számára. Ez a megközelítés azonban nem vallana Durkheimre. Ô ugyanis elvetette azt a strukturalista nézetet, amely szerint a megfelelő ellentétpár felrajzolása, a fogalmi ellentétben felsejlő differencia felmutatása is jelentéskonstituáló erővel bír (Joas 2011: 92). Felmerül, hogy szent és profán különbségét egy társadalmi értékhierarchiához kellene kötni, így a szentséget mint a társadalom kiemelt értékét lehetne felmutatni. Ezt a lehetőséget azonban Durkheim maga veti el, amikor rámutat, hogy egyes szent dolgok (pl. különböző fétisek, amulettek) nem váltják ki a hívők tiszteletét. Sőt bizonyos vallásokban a „hívők” nem érzik magukat alacsonyabb rendűnek isteneiknél, és a fizikai kényszertől sem riadnak vissza, ha kívánságaik teljesítését akarják kicsikarni belőlük (Durkheim 2003: 45-46). Az a definícióban rejlő megoldás sem áll biztos lábakon, amely a szentséget pusztán a társadalomban előforduló tilalmak felől azonosítja. Durkheim is elismeri, hogy bizonyos helyzetekben a szent dolgok is tilalommal vannak sújtva. Igaz, szerinte ez a tilalom is azt szolgálja, hogy a szent és a profán elkülönüljön egymástól.

Durkheim a meghatározásnál végül egy tapasztalatra hivatkozik, amely szerint az egyénekre egészen eltérő társadalmi formációkban is igaz, hogy a szentnek tekintett objektummal találkozva erő jelenlétét élik meg. Ezt az erőt a profán személy „átvándoroltathatja” magába, és úgy érzi, hogy tisztátalanként valami tisztából részesül. Durkheim egyes kritikusai úgy vélik, hogy az „erők és energiák átvándorlásáról” szóló megfogalmazás mögött az a szándék húzódik meg, hogy a társadalmi mozgásokat végül a társadalmi szubjektumok mélyebb tanulmányozása nélkül, természettudományos analógiára, erők és ellenerők játékaként lehessen leírni. Joas szerint azonban Durkheim gondolatmenete mögött William James pragmatista filozófus meglátása fedezhető fel (Joas 2011: 93). Eszerint a vallásos egyének kognitív meggyőződéseiben, teoretikus formában kifejtett hittételeiben nincsen semmi olyan, amiből a társadalomtudós meg tudná érteni cselekvésük, vallásos közösségben való együttmúködésük mélyebb okait. Az okok feltárása csak egy sajátos dinamika megértésével lehetséges. Ha felismerjük: a vallási közösségek tagjai bizonyos „objektumok” köré spontán, tehát nem tudatos módon rituálék és közös cselekvések olyan rendszerét építik ki, amelyhez kapcsolódva a közösség erejét saját életerejük forrásaként élhetik meg. Hogy egy-egy közösség tagjainak közös világképe lehet, amelynek kontextusában a kaotikus világ rendezetten jelenik meg, és e világban az egyének saját helyüket is meglelik, az annak az intenzív tapasztalatnak köszönhető, amit e cselekvésbe bekapcsolódva megélnek.

5 Az ellenérv következetes kifejtését ld.: Spiro (1966: 89). 


\section{A modernség „rituáléi” és a büntetés logikája}

E vallásszociológiai megfontolások áttekintése után Joas azokra a kortárs megközelítésekre hívja fel a figyelmet, amelyek különböző „szekuláris” világképek létrejöttét is szakralizációs folyamattal magyarázzák. Ezek szerint a szekuláris nacionalizmus, a marxista szocializmus és a harcos liberalizmus is azért vált egységesítő erővé, mert létrehozta saját szent „objektumait” és rituális cselekvési formáit. Gondoljunk a „szent hazában”, a „pártban”, a „forradalmi munkásosztályban” vagy az „elidegeníthetetlen emberi jogokban" való hitre, a nemzeti vagy a munkásmozgalmi panteonokra, az ezek köré épülő ünnepi felvonulásokra, a vallási ünnepek mellett megjelenő nemzeti és nemzetközi ünnepekre, eskütételekre, hitvallásokra. Vélhetően ezek azok a példák, amelyek Joas számára azt mutatják, hogy a szentség és a vallás hagyományos definíciós összefüggése megfordítható. A szent fogalma nem vezethető le a vallásból, a szakralizálódás minden kultúra kifejlődését meghatározó folyamat. Persze a szentség a vallás számára is konstitutív, de vallás csak akkor jön létre, ha a szentség köré épülő hitvallások, gyakorlatok szisztematikussá, egy domináns társadalmi intézmény által meghatározottá válnak. A „társadalmi szervezettség” felől persze nehéz lenne megmondani, hogy a francia nacionalizmust, a szovjet típusú kommunizmust vagy a mainstream liberalizmust a durkheimi definíció értelmében miért nem nevezhetjük vallásnak. Joas Durkheim-interpretációjából viszont az a következtetés adódik, hogy a szakrális/profán ellentétpár nem feleltethető meg a vallásos/szekuláris ellentétpárnak (Joas 2011: 94-95). A modern társadalmak formálódását olyan szakralizációs folyamatok felől is bemutathatjuk, amelyek a hagyományos értelemben vett vallási intézményektől egyre inkább függetlenül zajlanak le.

Egyelőre térjünk vissza eredeti kérdésünkre: végül hogyan interpretálható a Joas által vizsgált transzformációs folyamat? Beccaria-kritikájából az következik: annak adekvát története, hogy a nyugati ember hogyan gondolkodik a másikkal szembeni büntetésről, akkor mondható el megfelelően, ha feltételezzük, hogy mindig a szentségek megsértése volt a legsúlyosabb bűnként számon tartva. Láthattuk, hogy a profán személyek megsértése, megölése a történelem folyamán általában nem volt jelentős bűn. Másfelől: a Foucault-elemzésekből Joas azt szűrte le, hogy az abszolutista büntetési rend tanulmányozásán keresztül rá lehet világítani a nyugati büntetési rendszer logikájára. Így a vizsgált transzformáció úgy írható le, hogy a modern jogrendben és morális közfelfogásban az Isten kegyelméből uralkodó, sérthetetlen uralkodó helyére fokozatosan az ,individuális személy” került. A vele szemben szóban vagy tettben megnyilvánuló támadást nem egyszerúen az anyagi károkozás racionális-jogi modellje szerint, inkább a felségsértés analógiájával kell leírnunk. Így - adódik a következtetés - eredeti értelme szerint a modern büntetést olyan tevékenységként kell értelmeznünk, amelynek során a társadalom tagjai rituálisan helyreállítják az individuális személyekre épülő hatalmi egyensúlyt. 
Ez a felvázolt Durkheim-interpretáció nézőpontjából egy általánosabb társadalomképpé bővül. Eszerint a „személy szakralizációja” kifejezés ${ }^{6}$ a modern társadalom kialakulásának egy jellegzetes folyamatára utal, melynek során az individuális személy köré különböző tilalmak, hitek és közös gyakorlatok épülnek azért, hogy a társadalom tagjait a korszak kihívásainak megfelelően átfogó morális közösségben egyesítsék. A bemutatott Durkheim-elemzés értelmében Joasnak a modern társadalom egy olyan rekonstrukcióját kéne megalkotnia, amelyben a modern intézményrendszer e szentség köré épülő, annak „erejéből” táplálkozó közös cselekvési formaként modellezhető. És azt a feltevést is igazolnia kéne, hogy a társadalmi szereplők partikuláris hitei mögött egy átfogó „világkép” is kirajzolódik, amelynek sarokköve az individuum.

Kritikusan megjegyezhetjük, hogy Joas végül adós marad egy ilyen átfogó társadalom- és világkép rekonstrukciójával - csak azt vizsgálja, mennyiben nyújt adekvát magyarázatot a büntetőjog és a fegyelmezés történetében bekövetkező változásokra. Azt viszont meggyőzően mutatja be, hogy Durkheim elméletének nézőpontjából több olyan jelenség megmagyarázható, amelyek Beaccaria vagy Foucault elméletében nem voltak értelmezhetőek. Beaccaria elméletének szempontjából nehezen volt megmagyarázható, miért sújtja morális megvetés az öngyilkossági kísérletet végrehajtó személyt - ha a modernség egyik felismerése éppen az volt, hogy a racionális egyén saját élete felett szabadon rendelkezik. A kulcs Joas szerint az, hogy az új modern moralitás alapja nem a személyes belátás szerinti önrendelkezés, hanem a racionális alapon nem indokolható hit, hogy saját testem és személyem „szent”, így saját önkényes beavatkozásaimmal szemben is tiszteletet és védelmet érdemel. ${ }^{7}$

E mélyen gyökerező kulturális sajátosság nézőpontjából világítható meg a modern büntetési-fegyelmezési rend logikája is. A modern egyén egy cselekvési rend részese, amelyben saját magát és a másikat mint érinthetetlen „szentséget” ismeri fel. Így azonban a kellő súlyú büntetés mérlegelésénél fontos dilemmába ütközik. A modernizáció kezdetén lezajló kulturális változások hatására szenzibilisebbek vagyunk mások fizikai bántalmazásával szemben, így a hatékony és elrettentő büntetés megtalálása az egyik legfontosabb közüggyé válik. Paradox módon azonban ugyanez a folyamat azt eredményezi, hogy a társadalom tagjai érzékenyebbé válnak a bűnöző szenvedésével szemben is. Azzal szemben is, akinek a legsúlyosabb vétséget, azaz az „érinthetetlen” emberi test és az emberi élet elleni bestiális támadást tulajdonítják. E dilemmára adott válasz a modern börtön megszületése. A „szabadságmegvonás” mint a büntetés tipikus formája azt a célt szolgálja, hogy az individuális személy elleni támadást ne a „szentség” újabb megsértése árán kelljen szankcionálni (Joas 2011: 98).

6 Durkheim rendszerint az individuum szakralizációjáról vagy az individuum kultuszáról beszél. Joas szerint pontosabb a személy szakralizációjáról beszélni: meglátása szerint a személy, személyiség fogalma az egyén társadalmi kötöttségeire erőteljesebben utal, és világosabban kifejezi az emberi élet szociális relacionalitását, így szembeállítható az egoista preferenciákat követő individuum képével (Joas 2011: 83-84; Dirscherl-Dohmen 2013: 71).

7 Joas ezt a gondolatot később az „élet mint ajándék" nyugati kultúrában és a zsidó-keresztény világban meggyökeresedett felfogására vezeti vissza (Joas 2011: 232-233). 
Empirikus megfigyelőként tehát Foucault-nak igaza van abban, hogy az új büntetési rend kialakulása nem csak a kínzás, a kínhalál háttérbe szorulásával, de a test fölötti kontroll növekedésével is együtt járt. Abban is, hogy e kontrollmechanizmusok később mintául szolgáltak különböző intézmények elnyomó mechanizmusainak tökéletesítéséhez. A változás hajtóereje azonban nem az elnyomás új formáit intézményesítő absztrakt uralom, hanem egy olyan társadalmi integrációs mechanizmus létrejötte, amely valamilyen módon az individuális sérthetetlenség eszméjére épül. Joas nézőpontjából feltételezhető: vannak adekvát és inadekvát módjai annak, hogy a társadalomban érvényt szerezzünk a személy szakralitásával összefüggő elvárásoknak. Így Joas elmélete Foucault-éval szemben elméletileg azt is lehetővé teszi, hogy háttérbe szorítsuk az öncélú repressziót. Kérdés, hogy hogyan tudunk innen továbblépni Joas normatív elméletének rekonstrukciójához.

\section{Történeti szociológia és filozófia}

Joas történeti elemzése arra a feltevésre épült, hogy a büntetés és a fegyelmezés történetét vizsgálva bemutatható egy a 18. század elejére tehető változás, melynek során az emberi test szenvedését célzó kínzás a büntetésnek és a fegyelmezésnek egyre kevésbé legitim eszköze. Bemutatta, hogy a változás lényegét legmeggyőzőbben Durkheim társadalomelmélete fejezi ki, amely szerint a változás hátterében a kiterjedt, komplex társadalmak integrációjának kihívása állt. Joas úgy gondolja, hogy a durkheimi feltevés értelmében minden társadalom és kultúra fejlődésének alapja a szentség (egyház, méltóságok, uralkodó, szent objektumok stb.) jelenléte, amely köré spontán módon a jól koordinált cselekvések rendszere épülhet fel. A feltevés szerint ez a modern társadalomban sincs másképp, csak a működő társadalmak „szakrális magjává” (Joas 2011: 81) az egyházi vagy világi méltóság helyett az individuális személy vált.

Joas elméletének szellemében azt mondhatjuk, hogy az emberi jogi normák érvényességének alapja nem egy racionálisan bizonyítható alapelv, hanem a jól integrált társadalmak tagjainak egy alaptapasztalata. Az egyén az egyik oldalról a sérelmek és a megalázás változatos formáival szembesül. Ezeket a tapasztalatokat az az intézményrendszer strukturálja, amely egyre inkább az egyenlőség formális elismerésére épül. Az egyén így a modern cselekvési rendszer részeként saját magát és a vele szembenállót újra és újra mint egyenlő emberi méltósággal megáldott személyt ismerheti fel. Az emberi jogi doktrína ezek szerint valamiképp e fontos inspirációs forrást képező alaptapasztalatnak és normatív következményeinek a teoretikus megragadása (Möllers 2011). Probléma azonban, hogy Joas e normák jelentőségét a társadalmi funkciójuk nézőpontjából mutatja be. Így viszont továbbra is kérdés: a durkheimi elmélet perspektívájából mondhatunk-e bármit a normák érvényességéről? További feszültséget jelent, hogy Durkheim és Joas vallásszociológiai perspektívából világítja meg az emberi jogi normák érvényességének alapjait. E nézőpontból viszont - Joas szándékaitól eltérően - megnő a távolság a teoretikus nézőpont és az 
elvileg azonosulásra méltó normák között. A megközelítés elsőre azt sugallja, hogy az emberi jogi normák kialakulásának vizsgálata emocionálisan éppúgy érintetlenül kell hogy hagyja a kutatót, mint ha a távoli múlt vagy távoli világok vallási praktikáinak funkcionális szerepét vizsgálná.

Egy lehetséges megoldás felvázolásához érdemes arra a történeti kontextusra is figyelmet fordítani, amelyben Durkheim elmélete megszületett. Ahogy arra Joas is felhívja a figyelmet, a személy szakralizálódásáról szóló gondolat megszületésének közvetlen motivációját a Dreyfus-per adta. A hivatalos propaganda és a hadsereg álláspontja az volt, hogy a zsidó tiszt mellett kiálló értelmiségiek szem elől tévesztették a haza érdekét, anarchisták, akik nem hisznek semmiben, de az individuumot a szentség rangjára emelték. Durkheimnek eredetileg ez az érvelés adott lökést ahhoz, hogy feltárja az individualizmus fogalmában rejlő kettősséget. Ahogyan az elemzés korábbi részében láttuk: az „egoista individualizmussal” végül a „megfelelően értelmezett individualizmus” pozícióját állította szembe, azaz egy olyan, már mélyen meggyökeresedett normarendszert, amely a modern társadalmi integráció és az egyéni autonómia elismerésén alapuló morál alapja. Döntő jelentőségű, hogy Durkheim ezt a normatív rendszert vallási kontextusban mutatja be. Így az a vád, hogy a Dreyfus-pártiak az individuumot emelték a szentség rangjára, egy csapásra elveszti negatív konnotációját. Az individualizmus Durkheimnél vállaltan a „modernség vallásaként” jelenik meg, Durkheim pedig e „vallás” híveként átszellemülten artikulálhatja álláspontját, amely szerint egy individuum becsületének megsértése egy szentég meggyalázásával azonos súlyú bűn (Durkheim 1986).

Talán e nézőpontból rajzolódik ki Joas pozíciója is. Joas Durkheim-elemzésében szembefordul azzal a (pl. Beccariánál megjelenő) felvilágosult állásponttal, amely szerint a normák érvényessége racionális filozófiai vitában dől el, és amely a jogok érvényességét a felvilágosult törvényhozó szentesítéséhez köti. Az érvényesség megállapításához nincsen más végső kritériumunk, mint annak megállapítása, hogy bizonyos normák a társadalom tagjainak átfogóan inspirációs forrást képeznek, e normákra a kényszermentes együttmúködés mechanizmusai épülnek, és alapvetően strukturálják az egyénnek a világról alkotott felfogását. A normaérvényesség feltételei így egy mélyre nyúló társadalmi folyamatban alakulnak ki, amelyre a teoretikus csak korlátozott mértékben lehet hatással. Joasnak a bűnről, a büntetésről, az individualizmusról és az emberi méltóságról szóló durkheimiánus elemzései azonban arra is rámutatnak: a teoretikus nem csak arra lehet képes, hogy elmondja a meghatározó normák hiteles történetét. Arra is képes, hogy rámutasson e normák adekvát és inadekvát értelmezéseire. Hogy ezáltal rávilágítson, hogyan teljesedhet ki az emberek szabadság vagy igazságosság iránti vágya az adott történeti-kulturális feltételek között. ${ }^{8}$

8 Joas e gondolattal szoros összefüggésben, könyvének 4. fejezetében Ernst Troeltschre hivatkozva egy olyan koncepció kidolgozását szorgalmazza, amelynek normatív szempontja nem „örökkévaló normákhoz”, hanem egy-egy korszak társadalmának tagjai által hallgatólagosan előfeltételezett „ideálok” azonosításához kötött (Joas 2011: 156-164). 
Kérdés, hogy e teoretikus eljárásában milyen szerep jut a klasszikus morál- és politikai filozófiai érvelésnek. Talán Joasnak abba az észrevételébe kapaszkodhatunk, hogy Durkheim a „személy szakralitásáról” szóló gondolatának bevezetésekor filozófiai példákra, mindenekelőtt Rousseau és Kant morálfilozófiájára hivatkozik (Joas 2011: 83). Ezeket tartja tehát a követésre méltó „individualizmus” megfelelő filozófiai artikulációjának. Peter Fonk német morálteológus Joas könyve kapcsán amellett érvel, hogy a kantiánus filozófia és a joasi szociológiai megközelítés nem egymás gyökeres ellentétei. Egyrészt a kanti jogfilozófia is egy reális társadalmi megfigyelésen alapul: azon a feltételezésen, hogy egy „összezsugorodó világban”, ahol az eltérő kultúrákból érkező egyének találkozása gyakrabbá válik, a konfliktusok feloldása csak általános és észszerű formára hozható alapelvek mentén lehetséges. De Fonk szerint Joas érvelése sem hagyja figyelmen kívül a kanti filozófia eredményeit. Inkább annak feltárására törekszik, hogy milyen motivációs forrásai vannak az olyan társadalmak tagjainak, amelyek általános jogelvek alapján integráltak. Míg tehát Kant filozófiája azzal a kérdéssel foglalkozik, hogyan generalizálhatók a mindenki által elfogadható, legitim morális alapelvek, Joas elmélete arról szól, hogyan válnak ezek a köznapi életünkben motiváló princípiumokká (Fonk 2013: 128-129). Höffe kritikáját tehát tompíthatjuk: Joas művében a szociológiai szempont nem szorítja ki a filozófiai érvelést, inkább egy komplementer viszonyt feltételez. Eszerint a kényszermentes társadalmi együttműködést lehetővé tevő normák filozófiai érvelés során fejthetők ki általános, elvszerű formában.

\section{Szakralitás és racionális diskurzus}

Ezen a ponton azonban a Joasszal szemben megfogalmazott kritikát érdemes újragondolnunk. Ahogy láttuk, Joas szerint a normák érvényessége végső soron bizonyos „szentségek” nem tudatos, társadalmi elfogadásától függ. Ez a gondolat alapvetően ellentmond a modern morál- és politikai filozófia feltevésének, amely szerint a normák érvényességének önkéntes, észszerủ és nyilvános beleegyezésen kell nyugodnia. Egy lehetséges válasz körvonalazásához érdemes figyelmet fordítanunk Joas Jürgen Habermasról szóló rövid észrevételére. Habermas A kommunikatív cselekvés elméletének egyik szöveghelyén a modernségbe való átmenetet „a szakrális nyelvivé válásaként (Versprachlichung des Sakralen)” jellemzi (Habermas 2011: 331-332). Egy olyan folyamatról ír, amelynek során a „nyelv egyre inkább a vallás helyére” kerül. Közös szimbólumaink egyre kevésbé a szentség tapasztalata, mint inkább a kölcsönös megértésre irányuló kommunikáció során formálódnak. Később ez a gondolat vezet Habermas legitimációról szóló elméletéhez is: míg a tradicionális társadalmakban a vallási rituálé játszotta a legalapvetőbb szerepet a cselekvést meghatározó értékek kikristályosodásában, a modernség arra az előfeltevésre épül, hogy a normák érvényessége csak korlátozatlan, racionális diskurzusban tisztázható (Joas 2011: 95). Habermasnál így az egyik legradikálisabb szekularizációelmélet 
körvonalazódik: a modern legitimitás egyik legfontosabb alapfeltétele, hogy a diskurzus résztvevői ne hivatkozhassanak állítólagos „szentségekre”, és a diskurzusszituáció alapvetően felszabaduljon a rituális cselekvések hatása alól. Szakralitás és diszkurzív racionalitás ebben az értelemben egymást kizáró fogalmak.

Joas szerint Durkheim is elfogadja, hogy a kommunikáció normáinak térhódítása, a racionális érvelés kultúrájának elterjedése radikálisan átalakította a modern ember világképét, ideáljait (Joas 2011: 96). Durkheim több helyen elemzi azokat az intézményeket, amelyek az új kultúra elterjedésének letéteményesei: a modern parlamentet, a politikai vitafórumokat, a formális eljárást biztosító bíróságot. Azzal vélhetően Durkheim is egyetértene, hogy ezekben az intézményekben és ezeken a fórumokon a vita résztvevői (a későbbi, habermasiánus szóhasználattal) a „kommunikatív racionalitás" normáinak elfogadását várják el egymástól. A későbbi habermasi felfogáshoz képest azonban sokkal inkább az a hangsúlyos, hogy ezek problémamentes fenntartása egy mély érzelmi kapcsolaton alapul, amely minket a különböző gyakorlatokhoz és eljárásokhoz füz. Még a látszólag tisztán formális szabályok szerint működő tudományos vitaközösségek létrejötte és múködése sem magyarázható pusztán a kommunikatív racionalitás standardjainak intézményesítéseként. Fennmaradásukhoz elsősorban a tudományos ethosz meggyökeresedésére volt szükség, amely a feleket kvázi-rituális közös cselekvések során a vitában való intenzív részvételre motiválja.

Még fontosabb, hogy a parlament, a bíróság és a tudományos közösség problémamentes múködése olyan társadalmi feltételeken alapul, amelyek megteremtése független a diszkurzív folyamatban részt vevő egyének tudatos szándékaitól. Fenntartásuk már előfeltételezi annak a történelmileg egyedülálló helyzetnek a létrejöttét, amelyben a felek minden korábbinál érzékenyebbé válnak a másik szenvedésére, azaz képessé válnak a másik perspektívájának átvételére, függetlenül annak társadalmi helyzetétől. Korábban éppen ezt a transzformációt magyaráztuk a személy szakralizációjával, a köré épülő kvázi-rituális cselekvési rendszer kialakulásával. Durkheim nézőpontjából tehát érdemes felülvizsgálni azt a gondolatot, amely szerint a szakralitáson és a kommunikatív racionalitáson alapuló normatív rendszer egymás riválisaként jelenik meg. Ha az érvényesség megállapításának racionális diszkusszióra épülő módja végleg háttérbe szorítaná a szakrális-rituális cselekvés jelentőségét, nem tudnánk számot adni annak a kohéziónak a forrásáról, amely lehetővé teszi a „diszkurzív” intézmények összetartását, újratermelődését. Durkheim gondolkodását követve ezért Joas azt a hipotézist fogalmazza meg, hogy a kommunikatív racionalitás normáinak előtérbe kerülése nem a szakralitás háttérbe szorítását, inkább egy modern szakralizálódási folyamatnak: a személy szakralizációjának sajátos „nyelvi kifejeződését” jelenti (Joas 2011: 96).

A racionális diskurzus joasi interpretációjához talán érdemes figyelmet fordítanunk két regensburgi teológus, Erwin Dirscherl és Christoph Dohmen elemzésére is. Ők amellett érvelnek, hogy Joas méltóságfogalmának megértéséhez a kegyelmi teológia szentségfogalmát kell alapul vennünk. Elemzésük szerint a „szentség” ter- 
mészete a kegyelmi tapasztalatban tárulkozik fel. Kegyelmi tapasztalatban érdemeinktől függetlenül részesülhetünk: Isten ajándékáról van szó, amelynek célja és rendeltetése az ok-okozati viszonyok, az érdem és a hasznossági relációk feltárására törekvő emberi gondolkodás előtt rejtve marad (Dirscherl-Dohmen 2013: 73). Az elemzés szerint a „szentség kvalitásához” egyrészt a „szubjektív evidencia” képzete társul: anélkül jutunk biztos belátáshoz, hogy a belátás forrásáról racionálisan számot tudnánk adni. A „szentség” tapasztalata ráadásul nem kognitív bizonyosságot jelent, inkább intenzív érzelmet, amely anélkül sarkall cselekvésre vagy gondolkodásra, hogy az inspiráció forrásáról számot tudnánk adni.

A szentség e képe felől analógiás módon közelíthetünk az emberi méltóság fogalmához. Az emberi méltóság eszerint bizonyos társadalmi körülmények között „evidenciaként” jelenik meg a cselekvők számára: más normák érvényességét belőle eredeztetik, de forrásáról racionálisan nem tudnak számot adni. Az egyén egy jól múködő diskurzusközösség érvelő tagjaként is intenzíven élheti meg, hogy mind saját maga, mind a vele szemben álló másik egyenlő méltósággal rendelkezik. Egyszerre van szó egy inspirációs forrásról, amely a tagokat a vitában való részvételre sarkallja, és egy mély meggyőződésről, amely annak előfeltétele, hogy egymással gyakorlati kérdésekben észszerú vitát folytassanak. Azzal Joas is egyetértene, hogy az emberi méltóság normáinak társadalmi meggyökeresedése után a normáknak és a törvényeknek alapvetően racionális és szabad vitában kell igazolást nyerniük. Úgy gondolja azonban, hogy kivitelezhetetlen egy olyan teljes körü megokolási diskurzus, amely a normák érvényességének végső forrásáról is számot ad (Joas 2011: 72). Az igazolási eljárás szükségképpen meg fog állni bizonyos szubjektív és nem racionális módon elfogadott evidenciáknál, amelyeket a diskurzus résztvevői spontán módon elfogadnak, de amelyek mellett nem tudnak érveket felhozni.

Hogy mik ezek az evidenciák, arról Joas nem ír. Mindenesetre kézenfekvő arra gondolni: a nélkül az elvárás nélkül, hogy a másikat a vitaszituációban hallgatólagosan egyenértékűként fogadjuk el, aki társadalmi státusztól függetlenül elvileg nálunk jobb érv megfogalmazására képes, lehetetlen egy széles körű racionális vitát lefolytatni. Lehet diskurzus arról is, hogy ez az elvárás hogyan ölthet testet különböző társadalmi intézményekben, amelyek megfelelő keretet biztosítanak a viták lefolytatásához. A vitán belüli „egyenértékűség” elvárása azonban nem a diskurzusban nyer legitimitást: egy diskurzustól független, nem tudatos társadalmi folyamat során válik az életünket és gondolkodásunkat alapvetően strukturáló elvárássá.

Joas értelmezése szerint vannak tehát olyan normatív elvárások, amelyek a társadalom tagjaitól vagy a diskurzus résztvevőitől függetlenül alakulnak ki. Ebből az következik, hogy a társadalomkritikai nézőpont nem köthető pusztán a diskurzuselmélethez, a diszkurzív racionalitás normáinak számonkéréséhez. Van egy eredendőbb történeti nézőpont, melyből kiindulva a teoretikus fel tudja térképezni a nyugati típusú társadalmi fejlődésben megmutatkozó differenciákat, az individualizáció sikeres és patologikus változatait. Elvileg fel tud tárni olyan társadalmi 
körülményeket, amelyek felelősek lehetnek azért, hogy bizonyos társadalmakban a racionális diskurzus lehetősége a diszkusszió fórumainak megszervezése ellenére újra és újra elbukik. Rá lehet mutatni olyan társadalmakra, amelyekben az intézmények megszervezése nyugati minta alapján történik, a kényszermentes cselekvés lehetőségei mégsem adottak. Például azért, mert a társadalom tagjai nem ismerik fel a másikban az önmagukkal azonos értékű individuumot; vagy magukban sem látják a méltósággal rendelkező, sérthetetlen személyt.

\section{Összefoglalás és a nyitott kérdések}

Az eddigiek során azt láthattuk, hogy Joas gyümölcsöző módon interpretálta újra Durkheim társadalomelméletét. Egyrészt bemutatta, hogy adekvát módon csak egy újragondolt durkheimiánus pozícióból mondható el annak a transzformációnak a hiteles története, amely a kínvallatás, a kínzás, és sok helyen a halálbüntetés tilalmához vezetett a nyugati világban. E durkheimiánus perspektívából kirajzolódott az emberi méltóságnak egy lehetséges legitimációs alapja. Eszerint a modern társadalmakban az integráció, a kényszermentes együtt cselekvés olyan formái jelentek meg, amelyek lehetővé tették, hogy az egyének saját magukat és a velük szembenálló individuális személyt sérthetetlen „szentként” ismerjék fel. Egyúttal bizonyos esetekben képesek lesznek arra, hogy átélő, beleérző módon tudjanak azonosulni a másikkal, függetlenül annak társadalmi státuszától. Az emberi méltóság és a rá épülő emberi jogi normarendszer alapvetően nem racionális diskurzusban nyeri el legitimitását. Az elvi diszkusszió azonban egyike azoknak a modern kollektív cselekvési formáknak, amelyben az ember felfedezheti magában és a másikban a méltósággal rendelkező egyént, amelyben leginkább artikulálni tudja saját igényeit. A racionális diszkusszió mint kollektív cselekvés ugyanakkor fenntarthatatlan a perspektívaváltás lehetősége, a másik méltóságának hallgatólagos elismerése nélkül.

Joas elemzésében azonban mindvégig tisztázatlan marad a koncepció társadalomelméleti státusza. Az „átfogó kulturális transzformáció” problémájának középpontba helyezése arra utal, hogy Joas a „személy szakralizációjáról” szóló elbeszélést az egész nyugati modernizáció átfogó metanarratívájaként szeretné értelmezni (holott Durkheimnek vélhetően nem volt ilyen szándéka). Ha ez így van, akkor minden, a nyugati modernitásban tapasztalható tendencia, fejlődés vagy emberellenes pusztítás, stb. valahogyan e szakralizációs folyamattal, az azzal összefüggő inklúziós kihívásra adott adekvát és inadekvát megoldásokkal áll összefüggésben. Más szöveghelyek azonban arra utalnak, hogy a modernizációt inkább egy széles körű differenciálódási folyamatként kell felfognunk. Eszerint a modernizáció lehetővé tette, hogy a hagyományos vallási háttérről „leválva” párhuzamos szakralizációs folyamatok menjenek végbe. Így viszont kizárható egy mindent átfogó metanarratíva lehetősége: a „személy szakralizációja” csupán egyetlen tendencia, amelynek feltárása alkalmat adhat más gyökeresen eltérő „szekuláris hitrendszer” alapjainak felkutatásához. 
E kettősség miatt viszont igen nehéz végül megragadni, miben is áll a normatív teoretikus feladata. Kérdés például, merre induljunk, amikor a modern társadalmak legsúlyosabb patológiáit szeretnénk bemutatni, például amikor totalitárius vagy más embertelen rendszerek mibenlétének megragadására törekszünk. Ezek esetében a „nagy nyugati transzformáció”, a személy szakralizációjának félresiklásásról van szó? Hiszen e rendszerek létrejötte nem tûnik kivételesnek és átmenetinek. Vagy a növekvő inklúzióra vonatkozó elvárás félreértéséről, az „egyenrangú fél” rossz eszközökkel történő végrehajtásáról beszélhetünk, amely végül visszájára fordul és embertelenségbe torkollik (ahogyan Joas Foucault-kritikájánál láttuk)? Vagy a méltóság tömeges megsértésében a szentségek tudatos és kvázi-rituális megsértését kell felfedezünk (mint az oltárok lerombolásánál vagy a sírrongálásoknál)? Joas a legtöbb esetben arra hajlik, hogy a nagy társadalmi problémákat szembenálló szakralizációs folyamatok konfliktusának eredményeként írja le: az individuális moralitás eszménye például veszélybe kerül a faj, a nemzet vagy a társadalmi osztály szakralizálódási folyamata miatt. A halálbüntetés-ellenességről Joas azt írja, hogy újra és újra beleütközik az USA déli részén domináns nacionalista „civil vallás” ellenállásába. ${ }^{9}$ E magyarázattal azonban mintha feladnánk azt az értelmezést, amely szerint van egy domináns szakralizálódási processzus, amely így vagy úgy minden modern társadalmi változás eredője: az egyik „modern hitrendszer” a másik fölé kerekedhet, és tartósan meghatározhatja a cselekvő egyének világképét és (kényszermentesen) összehangolhatja cselekvésüket.

Így viszont a normatív elmélet konstrukcióját érintő kérdésbe ütközünk. Joas amellett érvelt, hogy a normatív teoretikus tevékenysége leginkább arra irányul, hogy a normatív rendszernek, amelyet ő maga is elfogad, megvilágítsa a történetét és adekvát megvalósításának lehetőségét. Az emberi jogok és a méltóság esetében azt láttuk, hogy legitimációjuk végső alapja az a másra vissza nem vezethető „szubjektív evidencia” volt, amely a megfelelő kollektív cselekvés során feltárul. Korunk multikulturális társadalmainak konfliktusait a joasi értelemben úgy jellemezhetjük, mint egymással szembenálló szakralizációs folyamatainak konfliktusát. Ha azonban ebben a helyzetben nincs teoretikus okunk, hogy a személy szakralizációjának, a hozzá kapcsolódó normatív elvárásoknak kiemelt jelentőséget tulajdonítsunk, mi magyarázza, hogy a normatív társadalomteoretikus nézőpontját az emberi méltósághoz (és ne mondjuk a nemzethez vagy bármely spontán módon létrejövő szakralizációs tendenciához) kapcsoljuk? Elemzésünk során azt láthattuk, hogy Joas fontos szerepet szánt a filozófus és a társadalomteoretikus elvszerü gondolkodásának a legitimációs eljárás során. De azt is láthattuk, hogy végső soron nem kapcsolódik egy univerzális nézőponthoz, amelyből mérlegelni tudna a szembenálló hagyományok között; így az is kétségbe vonható, hogy átfogó normatív társadalomkép megrajzolására lesz képes.

9 A halálbüntetés-vitában a személy szakralitásának elfogadása kerül konfliktusba az USA déli részén újra és újra erőre kapó nacionalista civil vallással (Joas 2011: 103-104). 


\begin{abstract}
According to Hans Joas's book,Die Sakralität der Perso”, the historical roots of human rights cannot be found in the anti-religious secularism but rather in a sacralisation process, during which modern societies create an „aura of sacredness” around their members. This thesis has been interpreted by many authors as part of a historical-sociological theory. Contrary to this, I argue that Joas's main aim was to establish a new methodology for the legitimation of human rights norms. I argue that the criticism of two authors (Cesare Beccaria and Michel Foucault) gave an opportunity for Joas to present a new theory, according to which telling the adequate history of the modern individual and discovering normative expectations that can be held against it are two processes that complement each other. I also demonstrate that the reference points of the new kind of normative theory can be assigned through the study of Joas' analysis of Durkheim's theory. At the end of my paper I confront the theory reconstructed in this way with the rational theory of rights based on the idea of public approval, thus, I try to outline the strengths and the weaknesses of such kind of a normative theory.
\end{abstract}

Keywords: sacralisation, human rights, human dignity, historical sociology, normativity

\title{
Irodalom:
}

Beccaria, C. (1967): Büntett és büntetés. Budapest: Akadémiai Kiadó.

Dirscherl, E. - Dohmen, Ch. (2013): Heiligkeit - Einzigkeit - Alterität. In: Laux, B. (ed.): Heiligkeit und Menschenwürde. Hans Joas' neue Genealogie der Menschenrechte im theologischen Gespräch. Freiburg: Herder.

Durkheim, É. (1986 [1898]): Der Individualismus und die Intellektuellen. In: Bertram, H. szerk,.): Gesellschaftlicher Zwang und moralische Autonomie. Frankfurt: Suhrkamp. Durkheim, É. (2001 [1893]): A társadalmi munkamegosztásrói. Budapest: Osiris.

Durkheim, É. (2003): A vallási élet elemi formái. A totemisztikus rendszer Ausztráliában. Budapest: L'Harmattan.

Fonk, P. (2013): Ethische Anmerkungen zur konstitutiven Bedeutung von Genesen. In: Laux, B. (ed.): Heiligkeit und Menschenwürde. Hans Joas' neue Genealogie der Menschenrechte im theologischen Gespräch. Freiburg: Herder.

Foucault, M. (1990): Felügyelet és büntetés. A börtön története. Budapest: Gondolat.

Habermas, J. (1981): Theorie des kommunikativen Handelns. Zur Kritik der funktionalistischen Vernunft, Band 2. Frankfurt am Main: Suhrkamp.

Habermas, J. (2011): A kommunikatív cselekvés elmélete. Budapest: Gondolat Kiadó. Honneth, A. (2003): Umverteilung als Anerkennung. Eine Erwiderung auf Nancy Fraser. In: Honneth, A. - Fraser, N. (eds.): Umverteilung oder Anerkennung? Eine politisch-philosophische Kontroverse. Frankfurt am Main: Suhrkamp.

Höffe, O. (2011): Was kann Kant dafür, dass er kein Soziologe war? FAZ, 2011. 11. 27. http://www.faz.net/aktuell/feuilleton/buecher/rezensionen/sachbuch/hansjoas-die-sakralitaet-der-person-was-kann-kant-dafuer-dass-er-kein-soziologewar-11543331.html.

Joas, H. (2011): Die Sakralität der Person. Eine neue Genealogie der Menschenrechte. Frankfurt am Main: Suhrkamp. 
Joas, H. (2017a): Die Macht des Heiligen. Eine Alternative zur Geschichte von der Entzauberung. Berlin: Suhrkamp.

Joas, H. (2017b): „A szekularizálódás és a modern világ”. In: Lázár Kovács, Á. (szerk.): Vallás - média - nyilvánosság. Új társadalomtudományi perspektívák. Budapest: Gondolat.

Möllers, Ch. (2011): Etwas am Menschen ist heilig. Die Zeit, 2011. október 13. https:// www.zeit.de/2011/42/L-S-Joas https://www.zeit.de/2011/42/L-S-Joas.

O'Neill, O. (2006): The Method of A theory of Justice. In: Höffe, O. (ed.): Klassiker Auslegen: Rawls: Eine Theorie der Gerchtigkeit. Berlin: Akademie Verlag.

Spiro, M. E. (1966): Religion: Problems of definition and explanation. In: Banton, M. (ed.). Anthropological Approaches to the Study of Religion. London: Tavistock.

Stein, T. (2007): Himmlische Quellen und irdisches Recht. Religiöse Voraussetzungen des freiheitlichen Verfassungsstaaten. Frankfurt am Main: Campus. 